\title{
Tonight Show dan Humorously Masculine
}

\section{Tonight Show and Humorously Masculine}

\author{
Johari Saputra ${ }^{1}$, Sumekar Tanjung ${ }^{2}$ \\ ${ }^{1,2}$ Program Studi Ilmu Komunikasi, Universitas Islam Indonesia, Sleman \\ Yogyakarta, Indonesia
}

Author's email:
Email:
${ }^{1}$ johari.saputra@students.uii.ac.
id
${ }^{2}$ sumekar.tanjung@uii.ac.id

\begin{abstract}
Television is a form of development of information and communication technology media. Television broadcasts various programs, including the Tonight Show. Television broadcasts various programs, including the Tonight Show. The Tonight Show that was brought by Vincent and Desta was able to present funny and entertaining humor. Vincent and Desta always look masculine in every episode. This study aims to find out how the masculinity of Vincent and Desta's humor is displayed on the Tonight Show. The study used qualitative analysis. The results showed that Vincent and Desta's humorous masculinity was displayed with cognitive and affective differences in men, and humorous masculinity was displayed in affiliative (positive) and aggressive (negative) forms.
\end{abstract}

Keywords: Television, Tonight Show, Semiotics, Humor, Masculinity

Televisi merupakan wujud perkembangan media teknologi informasi dan komunikasi. Televisi menayangkan berbagai program acara, termasuk salah satunya adalah Tonight Show. Tonight Show yang dibawakan Vincent dan Desta mampu menghadirkan humor-humor lucu yang menghibur. Vincent dan Desta selalu berpenampilan maskulin di setiap episodenya. Penelitian ini bertujuan mengetahui bagaimana maskulinitas humor Vincent dan Desta tampilkan dalam Tonight Show. Penelitian menggunakan analisis kualitatif. Hasil penelitian menunjukkan bahwa maskulinitas humor Vincent dan Desta ditampilkan dengan perbedaan kognitif dan afektif yang ada pada pria, dan maskulinitas humor ditampilkan dalam bentuk afiliatif (positif) dan agresif (negatif).

Kata kunci: televisi, Tonight Show, semiotika, humor, maskulinitas 


\section{PENDAHULUAN}

Media televisi digunakan untuk menyampaikan informasi serta sarana hiburan. Televisi memanfaatkan bunyi dan gambar pada medianya yang bersifat informatif, hiburan, dan pendidikan. Tayangan televisi merupakan media audiovisual yang diartikan sebagai media yang mampu memberikan perantara, sehingga dapat digunakan oleh manusia untuk menyampaikan pesan kepada penerima yang ditujukan (Harjanto, 2005). Fenomena perkembangan televisi di Indonesia sendiri sejatinya telah dimulai ketika pemerintah mendirikan stasiun televisi milik negara, yaitu TVRI pada 24 agustus 1962 (TVRI, 2020).

Tayangan televisi yang dinikmati dan ditonton oleh banyak orang tentu melibatkan proses penyiaran di dalamnya. Penyiaran atau broadcasting merupakan proses penyampaian siaran yang dimulai dari tahap penyiapan, proses, bahan siaran, kemudian pemancaran sehingga penyiaran tersebut sampai kepada penerima siaran yaitu pemirsa (Wahyudi, 1994).

Pada saat ini, industri televisi sudah sangat berkembang, begitu juga di Indonesia. Tayangan televisi yang tayang di berbagai macam stasiun televisi harus mampu memberikan income terhadap stasiun televisi dengan berorientasi pada sistem rating. Secara teknis, tayangan televisi diartikan sebagai penjadwalan atau perencanaan siaran televisi dari hari ke hari (Horizontal Programming) dan dari jam ke jam (Vertical Programming) setiap harinya (Soenarto, 2007:1).

Menurut Pandjaitan dan Iqbal (2006), orientasi sistem rating yang begitu keras memacu sebuah keinginan untuk meniru, bukan mencipta, dari para produser stasiun televisi. Ini menandakan bahwa sistem rating begitu memiliki pengaruh yang besar pada industri televisi.
Rating menjadi nilai jual bagi produsen televisi untuk mendapatkan income sebesar-besarnya dari sebuah tayangan program.

Televisi yang digunakan sebagai sarana hiburan, seperti adanya program acara ber-genre komedi dengan menyajikan humor. Program acara komedi yang ditayangkan di televisi-televisi Indonesia sekarang sudah dikemas secara kreatif dan inovatif. Salah satunya ialah program acara komedi yang dikemas dalam bentuk variety show yang menghadirkan bintang tamu, seperti Tonight Show.

Tonight Show adalah program acara yang dibawakan oleh Vincent dan Desta. Tonight Show merupakan suatu variety show yang sangat menghibur, dan memberikan berbagai informasi menarik dengan menghadirkan bintang tamubintang tamu dari berbagai kalangan. Pengemasan Tonight Show yang dikemas dengan begitu kreatif dan inovatif berbeda dengan variety show-variety show yang ada pada saat ini, ditambah dengan pembawaan dari Vincent dan Desta yang merupakan artis berlatar belakang komedian membuat Tonight Show digemari oleh para penonton.

Pada setiap episode Tonight show, Vincent dan Desta selalu menggunakan setelan pakaian jas serta sepatu pantofel di setiap episodenya. Mereka berdua selalu berpenampilan maskulin. Ini menunjukkan bahwa kedua pembawa acara ini ditampilkan sesuai dengan definisi pria di dalam ruang sosial. Mereka terarah berperilaku sesuai dengan definisi pria dalam berpenampilan serta bersikap sebagaimana mestinya pria. Maskulinitas telah diatur semenjak kelahiran dimulai dari bayi, kemudian selanjutnya akan diberi batasan-batasan sesuai jenis kelamin, dan memeroleh hak tertentu (Tanjung, 2015). Penelitian tentang 
humorously masculine ini dilakukan untuk mengetahui bagaimana maskulinitas humor Vincent dan Desta tampilkan dalam acara Tonight Show?

\section{LANDASAN TEORI}

Menurut Deviana (2018), maskulinitas dikatakan sebagai suatu konsep yang hadir sebagai konstruksi sosial. Berbagai konsep itu seperti watak, peran, perilaku, sifat, hingga definisi makna tertentu yang sudah dilekatkan pada pria. Menurut Demartoto (2012), berbagai aturan serta atribut mengenai maskulinitas telah di dapat dimulai dengan hal yang sederhana seperti ritual adat, ajaran agama, pola asuh, jenis permainan, jenis tayangan televisi, hingga buka bacaan dan filosofi hidup.

Maskulinitas terbentuk karena adanya fantasi bagaimana seharusnya seorang pria terbentuk, maskulinitas yang dikonstruksikan itu memberikan pandangan bagaimana pria harus menjalani kehidupan sosial sehingga mampu diterima dalam masyarakat. Dapat dikatakan bahwa maskulinitas sudah dikonstruksikan dan melekat pengertianya dalam kehidupan sosial masyarakat.

Menurut Kurnia (2004), konstruksi maskulinitas dibentuk dengan proses yang sangat panjang sehingga ia bersifat dinamis. Proses konstruksi maskulin muncul dari berbagai interaksi yang melibatkan banyak nilai yang berkembang di tengah masyarakat (Wibowo \& Wahyu, 2011). Perkembangan konstruksi masku-linitas dibagi menjadi dua bagian, yaitu maskulinitas konservatif dan maskulinitas modern. Perubahan dan perkembangan maskulinitas ini dipengaruhi oleh kapitalisme dan budaya konsumerisme. Di dalam dua eraperubahan ini, maskulinitas pada erakonservatif lebih memperlihatkan sosok pria maskulin yang lemah lembut, memperhatikan penampilan dan fashionable, sedangkan maskulin pada era-modern sekarang ini sosok pria yang diperlihatkan dengan lebih menonjolkan tubuh yang kekar, kuat, dan berotot. Oleh karena itu, menurut Tanjung (2015), tidaklah mudah menyimpulkan pengertian maskulinitas karena konsep itu diturunkan secara turun-temurun dan menyesuaikan dengan budaya setempat. Maskulinitas adalah konstruksi yang bersifat dinamis di kehidupan sosial masyarakat, dan menyesuaikan dengan perkembangan konsep dari mas-kulinitas.

Menurut Beynon (2002), ada berbagai macam faktor yang membuat definisi maskulinitas bersifat dinamis antara lain adalah perubahan sosial yang terjadi dan gerakan feminisme kaum perempuan untuk mendapati hak-hak mereka yang telah lama hilang akibat penindasan patriarki. Faktor lain adalah ekonomi, pendidikan, bahkan perang dunia dll mempengaruhi makna maskulinitas. Kimmel dan Aronson (2004) melakukan identifikasi tentang keberagaman maskulinitas. Kimmel menemukan empat hal tentang keberagaman maskulinitas. Pertama, maskulinitas memiliki perbedaan antara satu budaya dengan budaya lain. Kedua, maskulinitas di dalam masyarakat itu tidak statis tapi berkembang dari masa ke masa. Ketiga, maskulinitas itu berubah-ubah dalam siklus kehidupan seseorang. Keempat, pemaknaan tentang maskulinitas itu bervariasi dalam masyarakat. Namun, konstruksi yang dibentuk oleh masyarakat tentang definisi maskulinitas itu sendiri terkadang berbeda dengan kenyataan yang ada di masyarakat. Ini karena, Connell dan Messerschmidt (2005), hanya sebagian pria yang mampu ataupun bisa memenuhi kualifikasi sebagaimana maskulinitas itu diartikan dan telah ditetapkan oleh norma maskulinitas. 


\section{METODE}

Penelitian ini menggunakan paradigma konstruktivisme dengan mengambil teks sebagai objek kajian. Peneliti mengumpulkan data dengan menggunakan teknik dokumentasi, pengambilan gambar dilakukan pada objek penelitian yang berkaitan dengan humorously masculine yang ditampilkan oleh Vincent dan Desta dalam Tonight Show. Untuk teknik analisis data, peneliti menggunakan teknik analisis data deskriptif. Penelitian kualitatif dengan menggunakan teknik analisis deskriptif merupakan metode yang digunakan untuk mendapatkan data secara detail dan mengandung suatu makna (Sugiyono, 2012: 3). Teks dipilih ke dalam beberapa Scene untuk kemudian dianalisis dengan memfokuskan pada Scene humor yang dihubungkan dan maskulinitas.

Peneliti berhasil menemukan 12 data unit analisis yang berkaitan dengan maskulinitas humor pada Vincent dan Desta. Data unit analisis merupakan perencanaan data yang disusun secara rinci dalam penelitian. Oleh karena itu, peneliti telah menyusun beberapa unit analisis secara rinci dan detail, diawali dengan rentang waktu pengambilan sampel penelitian, episode, segmen dan dialog yang ditampilkan oleh objek penelitian.

Rentang waktu pengambilan sampel penelitian dilakukan pada episode yang ada selama bulan April 2020 yang terdiri dari episode 1715 sd 1733. Selanjutnya, peneliti telah membagi beberapa Scene yang terdapat pada episode Tonight Show selama bulan April. Pembagian Scene ini dimulai dari Vincent dan Desta melakukan opening Tonight Show, obrolan bersama bintang tamu, bermain games, sketsa drama, segmen tambahan hingga closing Tonight Show.
Pemilihan beberapa Scene yang tayang selama bulan April dipilih dan ditentukan beberapa saja karena menurut peneliti hal ini bisa menjadi gambaran secara keseluruhan bagaimana objek penelitian tentang humorously masculine digambarkan pada Vincent dan Desta dalam Tonight Show.

\section{HASIL DAN PEMBAHASAN}

\section{Relasi bromance menampilkan kebebasan humor}

Manusia berinteraksi untuk mewujudkan kehidupan sosial yang sesuai dengan nilai serta norma yang ada di masyarakat. Ini karena manusia sebagai makhluk sosial saling terikat dan bekerjasama dalam kehidupan. Interaksi yang dilakukan oleh individu akan membentuk hubungan secara positif ataupun negatif. Interaksi sosial yang baik akan menjadi penentu kualitas dalam hubungan yang sedang dila-kukan, interaksi yang menghasilkan hubungan positif tentunya akan menciptakan keakraban serta keintiman sehingga membentuk relasi pertemanan.

Argyle dan Henderson (1997) mengatakan bahwa hubungan pertemanan bromance pada pria merupakan hubungan yang terjalin secara baik, samasama saling menyukai, menyenangi kehadiran satu sama lain, kesamaan minat dan kegiatan, saling membantu dan memahami, mempercayai satu sama lain, serta menimbulkan rasa nyaman dan saling menyediakan dukungan sosial (Putri, 2016:4). Bromance yang mengindikasikan keakraban dan keintiman membuat satu sama lain sudah saling mengenal karakter masing- masing sehingga akan memberikan kebebasan dalam mengekspresikan perasaan serta emosional termasuk kebebasan dalam menampilkan humor yang bisa berupa kritikan, candaan dan ejekan yang 
diberikan kepada teman bromance nya. Hal ini tampak pada episode 1733 pada Scene 6 (00:02:34).

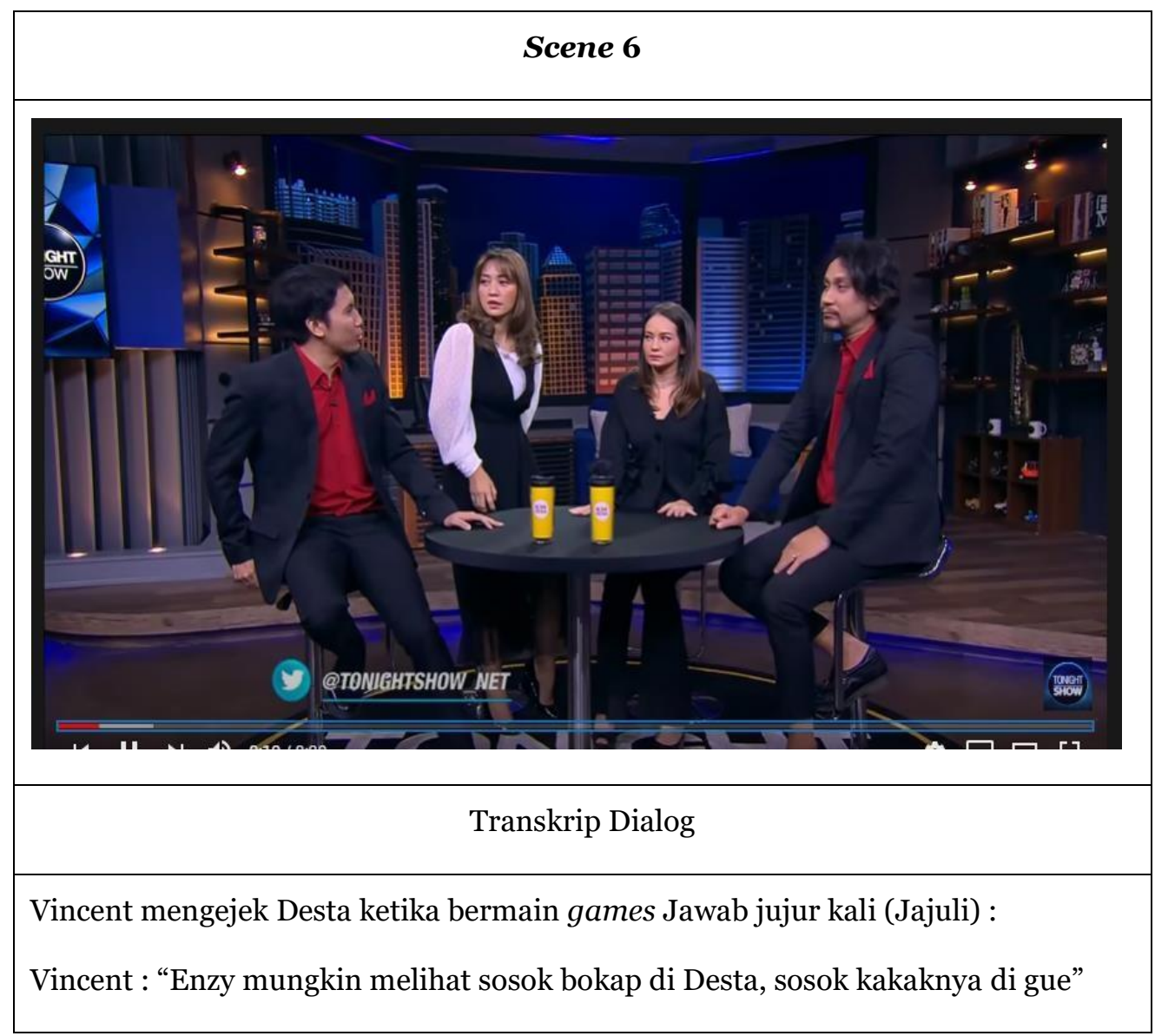

Vincent mengejek Desta yang lebih cocok menjadi bapak bagi Enzy karena Desta memiliki umur yang lebih tua dibandingkan Vincent. Hal ini adalah bukti bahwasanya hubungan bromance memberikan kebebasan dalam mengekspresikan perasaan serta emosional termasuk dalam menampilkan humor berupa ejekan dan candaan.
Humor berupa kritikan, candaan dan ejekan ketika dilakukan kepada individu yang tidak terikat secara bromance memiliki peluang ketersinggungan yang sangat besar meskipun dengan tujuan untuk menghibur. Humor yang memiliki keterikatan secara bromance terlihat pada episode 1726 Scene 2 (oo:08:24). 


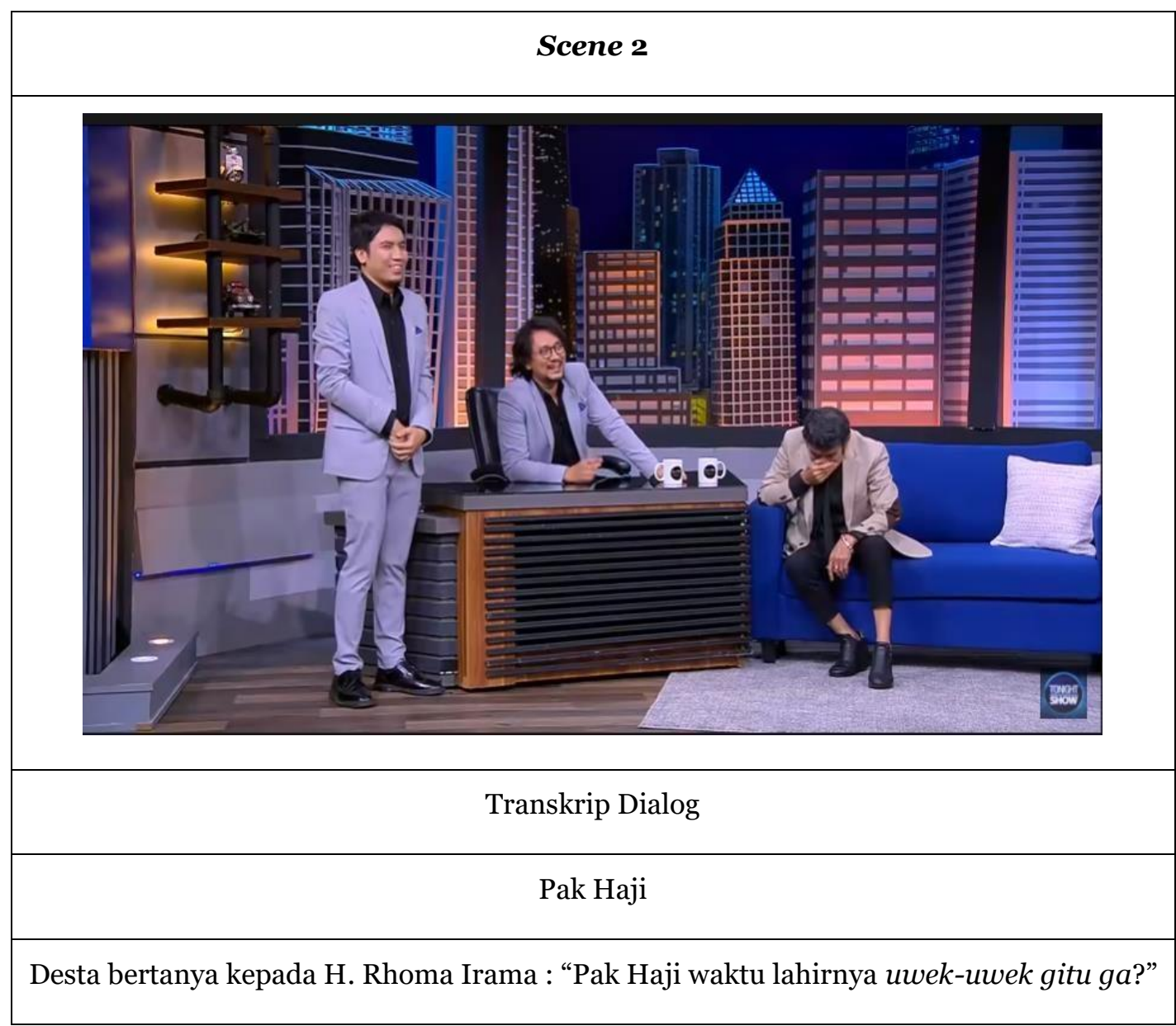

Desta berusaha menampilkan humor dengan menirukan suara tangisan $\mathrm{H}$. Rhoma Irama ketika kecil, tetapi Desta menampilkan humornya dengan nada suara yang sopan dan disertai panggilan Pak Haji ketika bertanya kepada H. Rhoma Irama. Hal ini merupakan upaya untuk menjalin hubungan yang positif serta bentuk sikap menghormati dari Vincent dan Desta kepada sosok H. Rhoma Irama. Namun, hal ini tentu berbeda ketika kritikan, candaan dan ejekan dengan tujuan menampilkan humor dilakukan kepada individu yang terikat secara bromance. Ikatan bromance secara tidak langsung memberikan kebebasan yang dipengaruhi adanya kedekatan yang intim, sudah saling memahami satu sama lain sehingga tidak akan menimbulkan ketersinggungan, sekalipun humor bersifat komedi gelap yang mengangkat bahanbahan humor dari hal yang sensitif seperti kemiskinan, penyakit dll. Candaan komedi gelap sebagai bukti adanya bromance ini terlihat pada episode 1723 pada Scene 10 (00:08:53) 


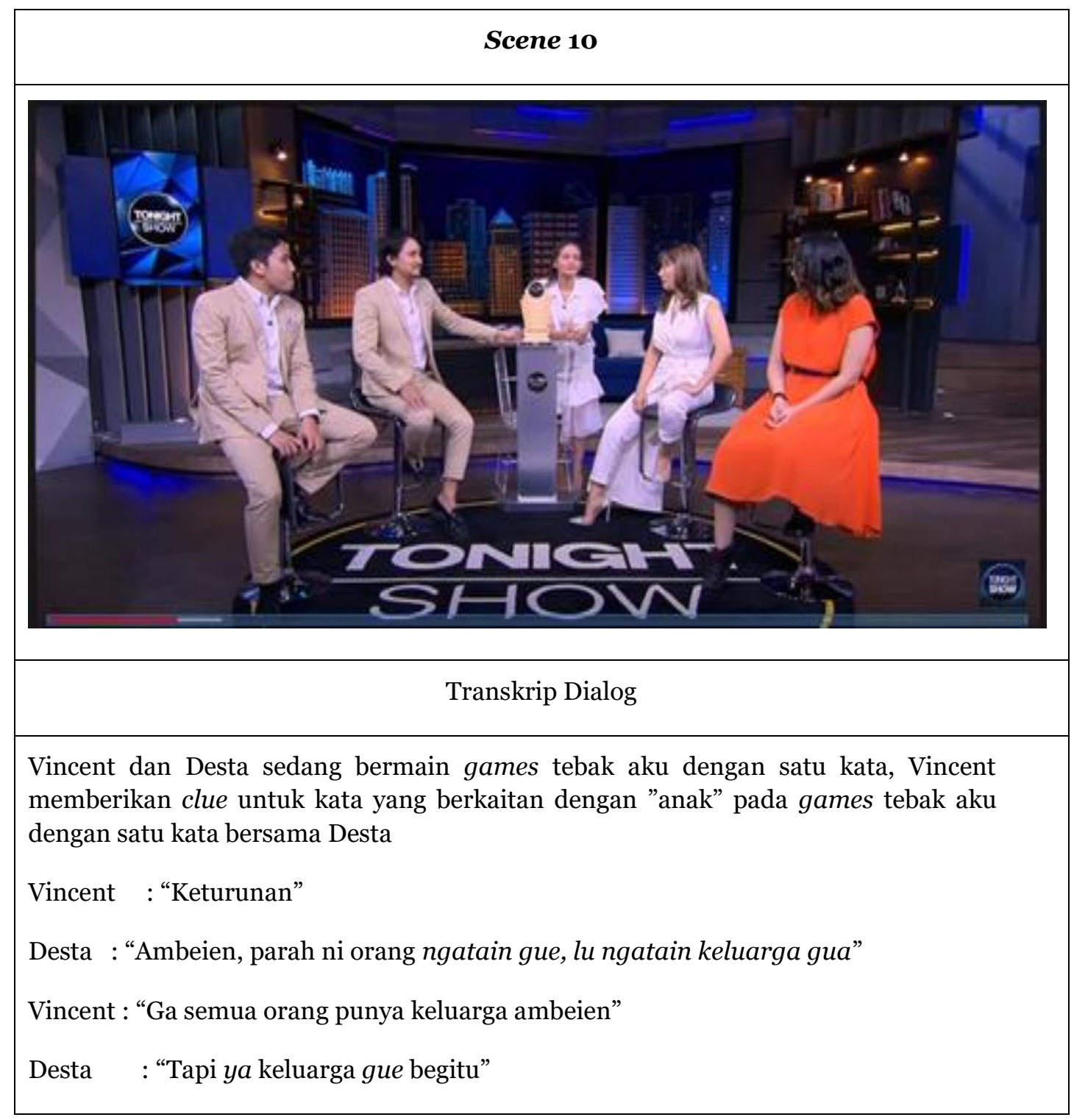

Desta menuduh Vincent yang dengan sengaja mengejek Desta yang menderita penyakit ambeien. Tuduhan Desta ini justru menampilkan humor yang menghibur para penonton meskipun humornya bersifat sensitif yang bisa mengakibatkan ketersinggungan.

\section{Atribut kognitif dan afektif maskulin menunjukan humor.}

Tiga atribut yang menjadi acuan perkembangan kemampuan berpikir individu karena proses pembelajaran disebut dengan teori Taksonomi Bloom yang meliputi kognitif, afektif, dan psikomotorik. Pada penelitian ini, yang menjadi fokus peneliti adalah atribut kognitif dan afektif maskulin yang ditunjukkan oleh objek penelitian.

Kognitif adalah segala hal yang berhubungan dengan nalar berpikir yang membuat otak mengembangkan kemampuan rasionalnya. Kognitif bertujuan untuk memeroleh pengetahuan yang didapat melalui percobaan, penelitian, penemuan dan pengamatan (Haryadi \& Aripin, 2015: 41). Pengetahuan yang diperoleh dengan berpikir kognitif dapat memengaruhi perilaku individu terhadap suatu hal. Ketika kognitif dibandingkan 
dengan afektif tentu sangat berbeda. Secara definisi, afektif adalah suatu hal yang berhubungan dengan psikis, jiwa dan rasa yang dimiliki oleh individu (Haryadi \& Aripin, 2015:42), termasuk di dalamnya representasi emosi dari individu tersebut.

Ketika kemampuan kognitif dan afektif dikaitkan dengan jenis kelamin tentu akan berbeda karena pria dan perempuan berbeda secara naluriah. Perbedaan jenis kelamin memengaruhi fungsi kognitif, khususnya pada memori individu (Pratiwi, 2019:16). Fungsi kognitif menurut Strub dkk adalah sebagai kemampuan atensi, memori, pemecahan masalah, pertimbangan, serta kemampuan merencanakan, me-nilai, mengawasi, dan melakukan evaluasi (Sibarani, 2014)

Perbedaan kemampuan kognitif bila dikaitkan dengan fungsi kognitif menurut Strub dkk, maka pria akan lebih mudah berpikir cepat dalam memanipulasi pengetahuan untuk dijadikan sebagai bahan humor seperti perbedaan budaya termasuk salah satunya perbedaan bahasa akan lebih mudah dilakukan oleh pria. Hal ini tampak pada episode 1719 Scene 1 (00:10:28).

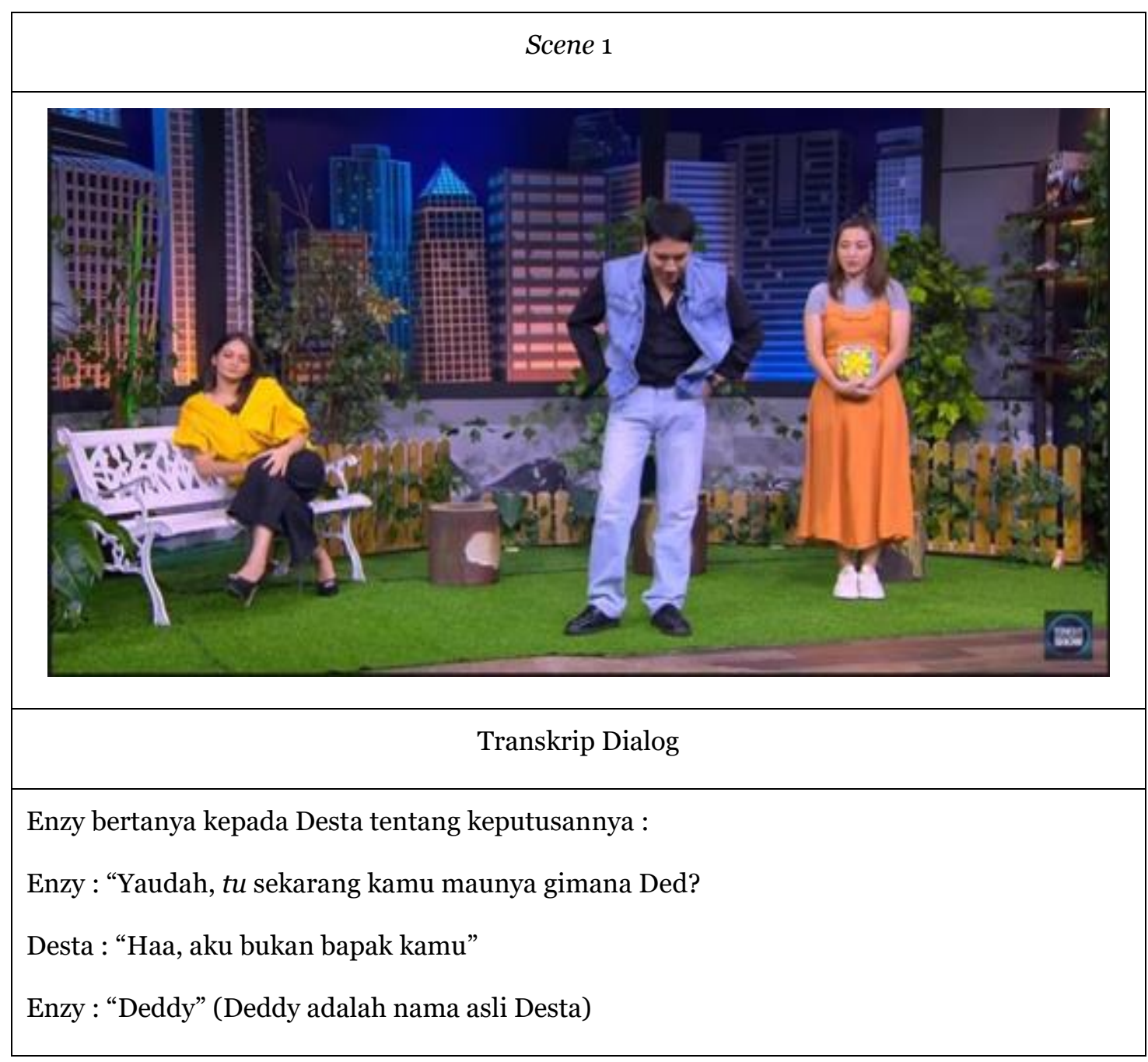


Desta menjadikan perbedaan bahasa sebagai bahan humor yang ditampilkan untuk menghibur para penonton. Bahasa merupakan perangkat dasar komunikasi dan modalitas dasar yang membangun kemampuan fungsi kognitif (Pratiwi, 2019:5). Kemampuan berpikir pria yang cepat dan lebih mudah dalam memanipulasi pengetahuan juga terlihat jelas ketika Vincent dan Desta memanipulasi kata dan kalimat menjadi suatu bahan humor yang dikenal dengan istilah pelesetan yang tampak pada episode 1719 Scene 1 (oo:10:44)

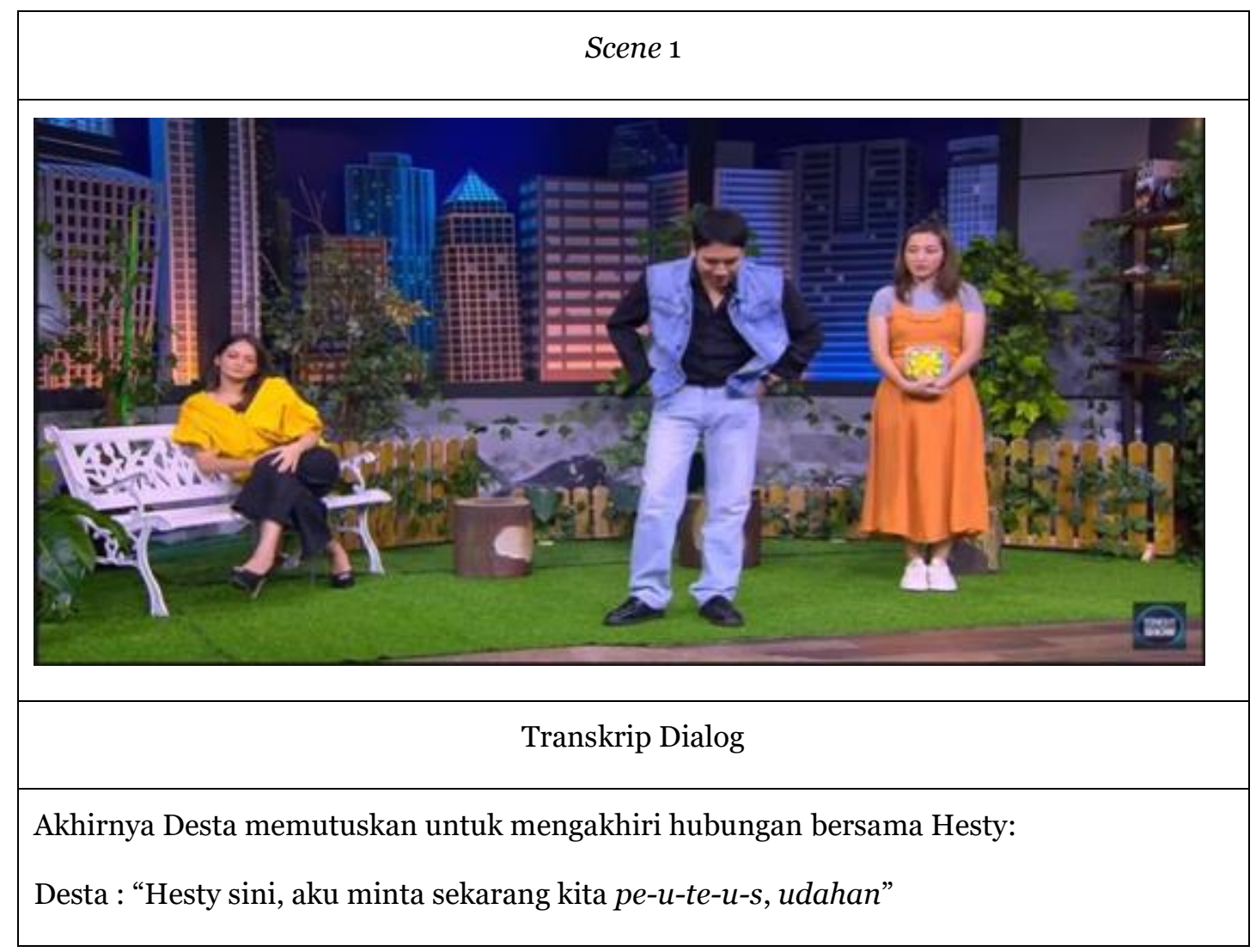

Desta memlesetkan dengan mengeja kata putus, tetapi yang disebut kata udahan. Bentuk humor plesetan ini membuat para penonton tertawa. Ini menjadi bukti bahwa kognitif pria akan lebih dominan dibandingkan dengan perempuan dalam menampilkan bentuk humor yang mengacu pada fungsi kognitif menurut Strub dkk. Gaya humor dengan memanipulasi perbedaan budaya, kata dan kalimat termasuk dalam teori humor menurut Manser (Rahmanadji, 2016), yaitu teori humor tentang pembebasan ketegangan atau pembebasan dari tekanan dengan memanipulasi suatu hal yang sudah diketahui dan dijadikan sebagai bahan humor untuk memeroleh kebahagian. Ini juga berlaku pada afektif maskulin. Afektif pria bisa menjadi bahan humor dengan memanipulasi afektivitas yang seharusnya menjadi karakter sosial afektivitas pria ditampilkan tidak sesuai dengan definisi karakter sosial afektivitas pria di masyarakat. Manipulasi ini bertujuan sebagai hiburan, hal ini tampak pada episode 1725 Scene 8 (oo:08:19). 


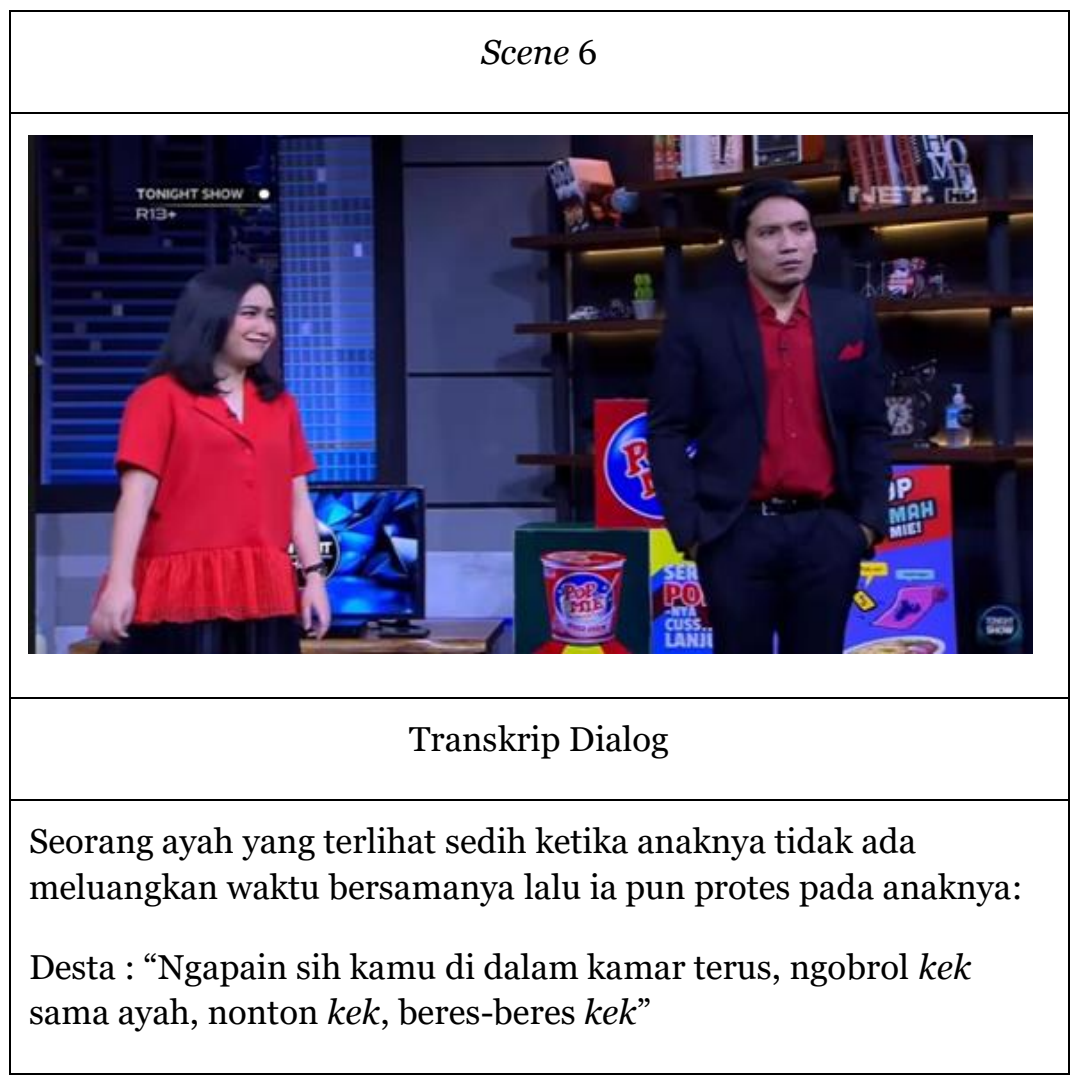

Desta yang berperan sebagai sosok bapak pada sketsa drama yang seharusnya terlihat kuat dan tegar, tapi justru terlihat sedih dan menangis. Manipulasi afektivitas yang ditampilkan oleh Desta pada episode 1725 Scene 8 (oo:08:19) merupakan bagian dari teori humor menurut Manser (Rahmanadji, 2016) karena memerlihatkan pembebasan ketegangan atau pembebasan dari tekanan dengan memanipulasi realita afektivitas maskulin pada pria yang seharusnya digambarkan kuat dan tegar. Namun, yang terjadi justru sebaliknya sosok Desta yang terlihat sedih dan menangis.

\section{Maskulinitas humor yang ditunjukkan dengan sikap afiliatif (positif)}

Setiap individu membutuhkan humor sebagai sarana untuk mendapatkan energi positif yang berfungsi untuk menghilangkan stres. Apabila humor dikaitkan dengan jenis kelamin, maka akan ada perbedaan karena jenis kelamin memengaruhi cara setiap individu melakukan interaksi untuk mewujudkan kehidupan sosial termasuk interaksi dalam memperlihatkan humor. Perbedaan pria dan perempuan memengaruhi karakteristik gaya humor yang disampaikan. Pria dan perempuan memiliki perbedaan dalam menyampaikan dan merespon humor (Fitriani \& Hidayah, 2012: 84).

Pada dasarnya, pria cenderung menggunakan humor yang bersifat agresif seperti mengejek, mencemooh, dan menghina (Martin et al., 2003). Namun, pria akan menggunakan sikap afiliatif sebagai gaya humornya ketika pria merasa ada jarak yang ditemukan dalam hubungan yang tidak menggambarkan keintiman. Ini tampak ketika Vincent dan Desta kedatangan bintang tamu $\mathrm{H}$. Rhoma Irama pada episode 1726 Scene 2 (oo:08:24). 


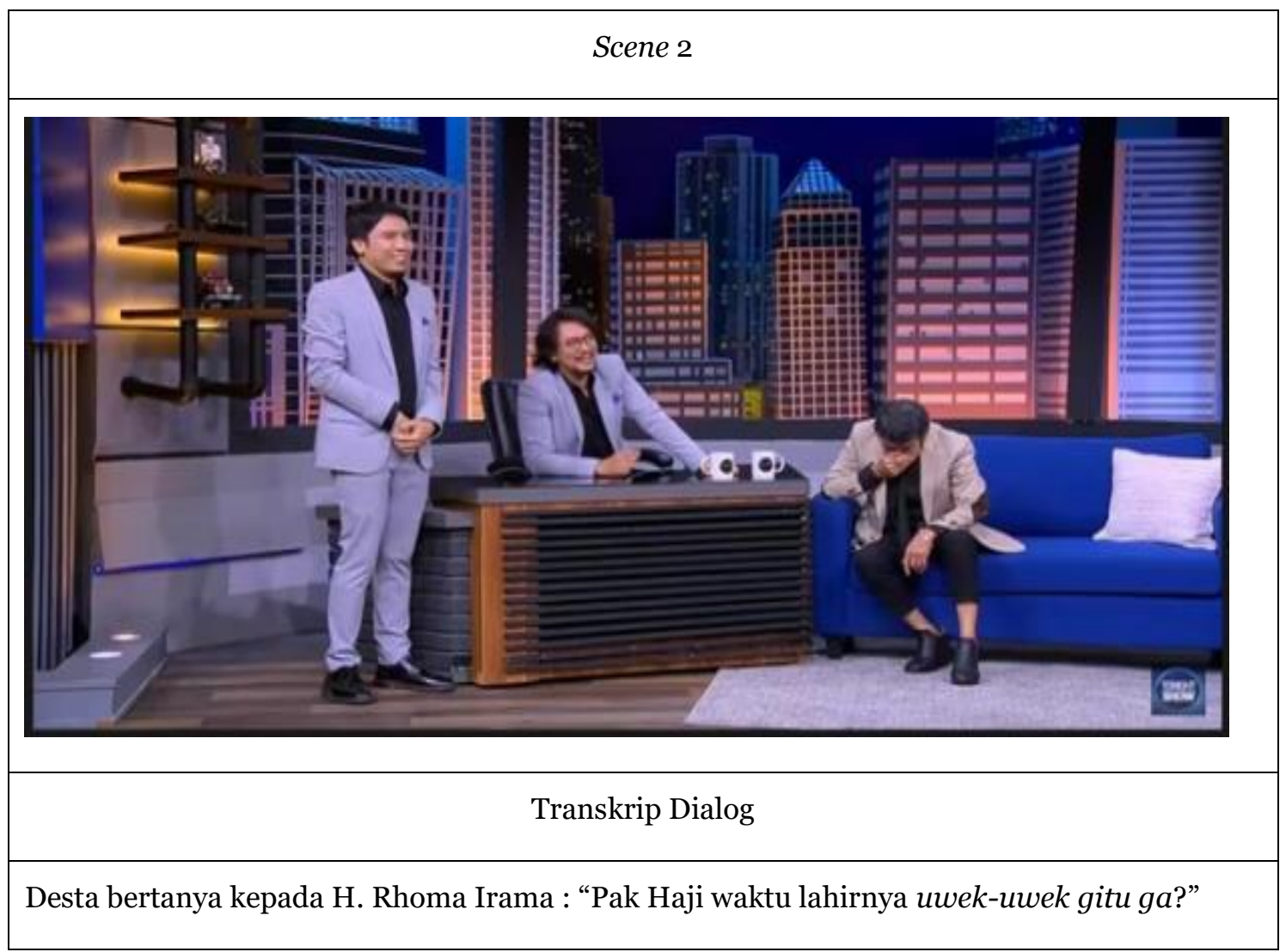

Vincent dan Desta tetap menampilkan humor-humor lucu, tetapi dengan tetap menunjukan kesopanan dan sikap menghormati sosok H. Rhoma Irama. Oleh karenanya, pria akan cenderung menampilkan sikap positif sebagai gaya humor yang digunakan ketika pria merasa bahwa hubungan yang ada tidak merepresentasikan keintiman dan keakraban sehingga pria bertindak aman dan berusaha menjalin hubungan yang positif sebagai gaya humornya.

\section{Maskulinitas humor yang ditunjukkan dengan sikap agresif (negatif)}

Ada berbagai faktor yang memengaruhi penyampaian dan penerimaan humor, salah satunya adalah perbedaan jenis kelamin. Fokus peneliti di sini adalah humor yang ditampilkan oleh kaum pria. Pria terkenal dengan sikap agresif dan aktif, sedangkan perempuan terkenal dengan sikap non-agresif (menerima) dan pasif (Mahmud, 2009:3). Ketika perbedaan jenis kelamin dikaitkan dengan sikap agresif sebagai suatu gaya humor yang ditampilkan, pria akan berani menunjukan humor yang bersifat mengejek, mencemooh, dan menghina tanpa mempedulikan ketersinggungan dari individu lain, hal ini tampak pada episode 1723 pada Scene 10 (oo:08:53). 


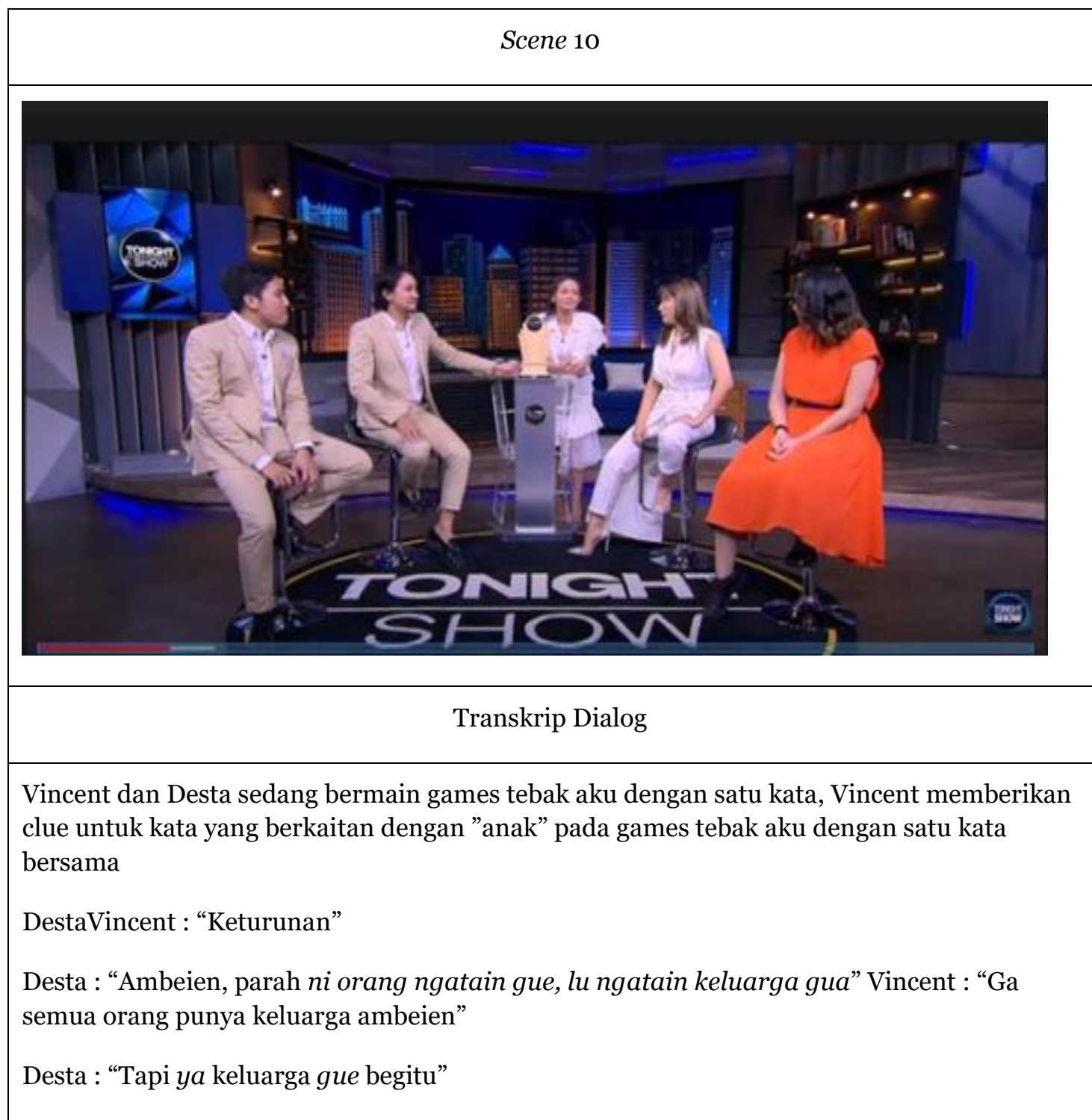

Desta menuduh Vincent yang dengan sengaja mengejek Desta yang menderita penyakit ambeien, tuduhan Desta ini justru menjadi hiburan yang mampu membuat penonton tertawa.

Sikap agresif sebagai suatu gaya humor diartikan sebagai humor yang cenderung mengejek, menghina, mencemooh orang lain yang bertujuan untuk mengkritik, menjatuhkan orang lain tetapi dengan maksud untuk menghibur (Martin et al., 2003: 53). Meskipun gaya humor agresif memperlihatkan kebebasan dalam menampilkan humornya ketika sikap agresif dilakukan sebagai gaya humor yang ditampilkan pada media tentu harus ada batasan dan aturan karena media bersifat publik sehingga perlu adanya kontrol dalam menampilkan sikap agresif sebagai gaya humor agar sesuai dengan aturan dan norma pada media yang bersifat publik.

\section{KESIMPULAN}

Maskulinitas bukan hanya dapat ditandai pada peran, karakter dan atribut sosial yang dimiliki oleh pria di dalam ruang sosial. Maskulinitas juga dapat ditandai dengan adanya perbedaan humor yang ditampilkan oleh pria. 
Penelitian bagaimana humorously masculine ditampilkan dalam acara Tonight Show yang dibawakan oleh Vincent dan Desta, diperoleh bahwa maskulinitas humor Vincent dan Desta pada acara Tonight Show dipengaruhi oleh faktor kedekatan atau keintiman yang disebut dengan istilah bromance. Adanya ikatan bromance membuat Vincent dan Desta berani menampilkan humor yang bersifat kritikan, ejekan, dan candaan sesama teman bromance-nya. Humorously masculine dalam acara Tonight Show yang dibawakan oleh Vincent dan Desta juga menampilkan humor dalam bentuk kognitif dan afektif pada pria. Secara kognitif, pria cenderung mampu berpikir cepat dan lebih melibatkan logika sehingga membuat pria mampu dengan cepat berpikir untuk memanipulasi pengetahuan menjadi bahan humor. Lalu, secara afektif, Vincent dan Desta sengaja memanipulasi karakter sosial yang seharusnya digambarkan oleh pria di masyarakat tetapi ditampilkan berbeda sehingga hal ini membuat penonton tertawa.

Vincent dan Desta juga menampilkan maskulinitas humor dengan gaya humor afiliatif. Gaya humor ini bertujuan untuk menghibur dengan bertujuan untuk memperoleh hubungan yang positif dan mencegah adanya ketersinggungan. Gaya humor yang bersifat agresif menampilkan kritikan, ejekan, dan candaan yang memungkinkan adanya ketersinggungan.

\section{DAFTAR PUSTAKA}

Argyle, H., \& Henderson, K. (1997). Friendship and social competence start. Developmental Psychology, 36(3), 326-338.

Beynon, J. (2002). Masculinities and culture. In Open University Press.

Connell, R. W., \& Messerschmidt, J. W. (2005). Hegemonic masculinity. Gender \& Society, 19(6), 829-859. https://doi.org/10.1177/0891243205 278639

Demartoto, A. (2012). Tubuh perempuan dalam konstruksi teoritik postmodernisme. Sosiologi: Dilema, $30(2)$.

Deviana, L. (2018). Representasi maskulinitas dalam iklan televisi (Analisis maskulinitas dalam iklan L-Men gain mass 'Kenny Austin' 2107) [Universitas Sumatera Utara]. http://repositori.usu.ac.id/handle/12 $3456789 / 5318$
Fitriani, A., \& Hidayah, N. (2012). Kepekaan humor dengan depresi pada remaja ditinjau dari jenis kelamin. HUMANITAS: Indonesian Psychological Journal, 9(1), 76. https://doi.org/10.26555/humanitas. v9i1.351

Harjanto. (2005). Perencanaan pengajaran. In Rineka Cipta.

Haryadi, T., \& Aripin, A. (2015). Melatih kecerdasan kognitif, afektif, dan psikomotorik anak sekolah dasar melalui perancangan game simulasi "Warungku." ANDHARUPA: Jurnal Desain Komunikasi Visual \& Multimedia, 1(02), 122-133. https://doi.org/10.33633/andharupa .v1io2.963

Kimmel, M., \& Aronson, A. (2004). Men \& masculinities: A social, cultural, and historical encyclopedia. In $A B C$ CLIO. 
Kurnia, N. (2004). Representasi maskulin dalam iklan. Jurnal Ilmu Sosial Dan Ilmu Politik, 8(1). https://doi.org/https://doi.org/10.22 146/jsp.11056

Mahmud, M. (2009). Perbedaan gender dalam berkomunikasi masyarakat Bugis. Jurnal Kajian Perempuan "Bunga Wellu,"14(1), 1-17.

Martin, R. A., Puhlik-Doris, P., Larsen, G., Gray, J., \& Weir, K. (2003).

Individual differences in uses of humor and their relation to psychological well-being: Development of the humor styles questionnaire. Journal of Research in Personality, 37(1), 48-75. https://doi.org/10.1016/So0926566(02)00534-2

Pandjaitan, E. L., \& Iqbal, T. M. D. (2006). Matinya rating TV. In Yayasan Obor Indonesia.

Pratiwi, A. (2019). Pengaruh brain training terhadap peningkatan fungsi kognitif diukur dengan Montrail Cognitive Assesment versi Indonesia (MOCA-INA) pada mahasiswa fakultas kedokteran Universitas Muhammadiyah Malang.

Putri, A. (2016). Hubungan antara persahabatan dengan self esteem. Jurnal Psikologi.
Rahmanadji, D. (2016). Sejarah, Teori, Jenis dan Fungsi Humor. 35 (2), Jurnal Bahasa Dan Seni, 35(2), 213221.

Sibarani, R. M. H. (2014). Perbandingan akurasi diagnostik antara cognitive performance scale dan mini mental state examination terhadap general practioner assessment of cognition untuk menilai fungsi kognitif pada usia lanjut [Universitas Sumatera Utara]. In Universitas Sumatera Utara.

https://repositori.usu.ac.id/handle/1 23456789/42048?show=full

Soenarto, R. . (2007). Program televisi. In IKJ Press.

Sugiyono. (2012). Metode penelitian kuantitatif kualitatif dan R\&D. Alfabeta.

Tanjung, S. (2015). Identifikasi strategi representasi maskulinitas pada majalah transnasional di Indonesia. Communication, 6(2). https://doi.org/10.36080/comm.v6i 2.45

TVRI. (2020). Sejarah-TVRI.

Wahyudi. (1994). Dasar-dasar manajemen penyiaran. In Gramedia Pustaka Utama. Gramedia Pustaka Utama.

Wibowo, \& Wahyu, I. S. (2011). Semiotika Komunikasi. Mitra Wacana Media. 